JUDr., Michal Janovec, PhD,

Faculty of Law, Masaryk University,

Czech Republic

\title{
INCOME TAX BASED ON REAL ESTATE LEASE
}

\section{Introduction}

There are many ways and possibilities to lease one's own real estate property intended for accommodation. All of these possibilities are the object of income tax of course, basically because there is simply an income.

The aim of this article is to analyze taxation of natural personal income, not the income of legal entities. In the law of the Czech Republic there is only one Act on Income Tax for both legal subjects - natural persons and legal entities, but only natural persons are interesting for us here, because the income type of legal entities plays no role for taxation, but there are some differences in taxation for natural persons, especially in the matter of lease or accommodation.

The purpose of leasing is to accommodate someone for a certain period, so differences between lease and accommodation are not very clear for the basic practical use of these terms. Real differences could be shown from the legal point of view for a lease contract and contract of accommodation. These differences could be very useful for real estate owners in order to decide which of these contracts could/must be applied in different cases of letting a flat, house or single room for the temporary use of somebody else. One of the most important factors for contract designing is the issue of tax, because in every country income tax is a "negative" part of the final income for the owner.

\section{Accommodation contract and lease contract}

The basic difference between a contract of accommodation and a lease contract is the fact that an accommodation contract is used for a shorter time period of housing (typically in hotels or hostels) and a lease contract is used for a longer period (a few months or years). Legal terminology also knows a short-term lease contract, which could be used for a shorter period, but only for flats and houses. So it looks like lease contracts are always used when somebody wants to lease a flat or house, but is this always true?

For many property owners who provide residential facilities to use or to lease to others the accommodation contract option is surely preferable at a time when problems occur with a user who, for example, does not pay the rent. In certain cases an accommodation contract cannot be used because of its very nature - it is designed for temporary occupation, for example hostels or university dormitories provide housing, which stays on the border between lease and accommodation, and almost always these institutions use an accommodation contract.

One of the questions I ask myself is whether the owner of a flat could provide dormitory-type housing, such as university dormitories, where part of the dormitory room is the bathroom and kitchen, and it is essentially a studio. Theoretically not, because the lease of the flat should be wherever it is a flat or house, but on the other hand, there is nowhere explicitly stated prohibiting providing a flat just for accommodation based on an accommodation contract. 
Legal practice constantly takes the view that when assessing whether a set of rooms (or single room) is a flat or not, it is necessary to proceed based on the constructed legislation; in this context, building approval status is crucial, rather than a factual way of usage. ${ }^{1}$

The Supreme Court of the Czech Republic published a definition of a flat which assumes the final decision of the Building Authority that a set of rooms (or single room) are eligible for permanent use and are intended for permanent housing. ${ }^{2}$

Based on my opinion, it is possible for the purpose of housing to let another person use a flat or house with a lease contract as well as an accommodation contract. It is a private law relationship, and if both parties agree with the accommodation contract, where the legal protection of this relation, especially the protection of the accommodated person, is far weaker, the autonomy of will is not prohibited.

The accommodation facility cannot be used for a lease contract, especially if it would be a long-term relationship providing permanent housing, only because of the characteristics of the accommodation facility, respectively the characteristics of the rooms that serve to accommodate in such facilities. This conclusion is supported by the Czech Civil Code, where it stands, that provisions of flat leases shall not be applied in cases of letting a flat or house for recreation, and apparently a short-term purpose. ${ }^{3}$

\section{Ordinary lease or business lease}

Business means an organization or economic system where goods and services are exchanged for one another or for money. Every business requires some form of investment and enough customers to whom its output can be sold on a consistent basis in order to make a profit. ${ }^{4}$

For the purposes of this article, it shows the basic and most important difference between incomes from ordinary (or just single) lease of real property and income of a profit-making business based on lease.

When there is a person owning one or two real estate properties, which are leased by himself, ${ }^{5}$ we clearly see the case of ordinary (not business) lease income.
On the other hand, when there is a person owning 10 different real estate properties, basically with the purpose of lease and further profit making, we do have a lease business here mainly based on two important signs. The first is the quantity of owned real estate properties and the second is the consistent basis of this activity ${ }^{6}$ in order to make a profit. This person also needs an administrative permit to run a business and have regular income from this activity.

\section{Ordinary lease characteristics:}

- small number of real estate properties owned and leased (typically one or two properties);

- family property or just randomly purchased property as an investment;

- not consistent basis of leasing.

\section{Business lease characteristics:}

- quantity; usually more real estate properties owned;

- systematic purchase of properties to make the portfolio of properties wider;

- the ONLY reason for purchasing the properties is to lease them in order to make a profit;

- consistent basis of purchasing properties and leasing.

This perhaps sounds a little complicated, but it is a big difference between different types of income (for tax purposes). When there is any kind of profit-making business (lease business included) it always has to be taxed the same way with the same tools, the same tax deductible expenses and with the possibility of lump sum expenses.

There has to be the existence of the above-mentioned differences of the lease, especially because there are many owners of single real estate property and they do not need it for housing themselves, their goal is not a real business, but to collect some extra money to maintain that property. They are allowed to have some extra income from the value of the property, since they do not operate with cash in an adequate amount as a value of their property.

\section{Lease, accommodation and income tax}

As was mentioned previously, both of these types of contracts are the subject of income tax. There are some 
differences in tax legislation for natural persons and their income tax, which is very important for contract type selection of the owners, but only in those cases where they could really decide and choose from these contract types.

Is the income from both contractual types the same or is there any difference? It is clear that income from these activities is the subject of Act no. 586/1992 Coll. the Income Tax Act, as amended, where $₫ 9$, which regulates lease income can be found. It is very clear, that lease income is regulated uniquely in this Act, unlike accommodation income, which belongs under $\$ 7$, where general business income and other self-employment activities are regulated. This section also deals with lease income if the real estate property is registered in the business property, listed in accountancy or tax records. This means that lease income is specific income of natural persons, but it cannot be regular profit-making business income.

Another important difference between income from accommodation and lease income, for the purposes of the Income Tax Act, is that accommodation is always business activity, but lease is only in some cases, as explained above in detail. In general, for tax purposes, accommodation is equivalent to business lease and it is under regulation $\$ 7$ of the Income Tax Act. The decision whether to use an accommodation contract or lease contract is also a decision between using $₫ 7$ and $₫ 9$ of the Income Tax Act.

However, what is the main difference for practical usage of $\S 7$ and $₫ 9$ of the Income Tax Act? Without any doubt, the main difference is the duty of social security and health insurance payment while using $\$ 7$, in other words an accommodation contract or business lease, and thus net income is lower. In both cases, lump sum expenses could be used. For a lease income, lump sum expenses are 30\% of income, with a max limit of CZK 600,000. Anyone can choose between lump sum expenses and real expenses, but it is not possible to change it during the tax year. Real expenses are also administratively more difficult. ${ }^{7}$

In relation to taxation of lease income, I would like to point out an interesting decision of the Supreme Administrative Court of the Czech Republic about the tax consequences of the non-valid lease contract. ${ }^{8}$

The decision underlines that for tax purposes in the context of public relations between the taxpayer and the tax administrator it is an important factual status compared to the private-law relationship of several taxpayers or a taxpayer with a third party. There was a void contract between two taxpayers, but one of the parties declared lease income and the other party applied tax deductible expenses, so they don't reflect the private law consequences of contract nullity. In other words, when both parties of the invalid contract behave like the contract is valid, then nullity of the contract has no effect on taxability of acquired income and deductibility of the costs. ${ }^{9}$

\section{Airbnb and housing provision income}

Airbnb is a trusted community marketplace for people to list, discover, and book unique accommodations around the world - online or from a mobile phone. Whether it is an apartment for a night, a castle for a week, or a villa for a month, Airbnb connects people to unique travel experiences, at any price point, in more than 33,000 cities and 192 countries. And with world-class customer service and a growing community of users, Airbnb is the easiest way for people to monetize their extra space and showcase it to an audience of millions. ${ }^{10}$

This marketplace is really an interesting area for analyzing taxation of lease income. The question is, whether income from using this marketplace is subject to taxation and if so, is it lease or some kind of accommodation contract? My own hypothesis states that it is the object of income tax only if it is provided for hosting regularly and it could be short lease or accommodation, but it is not ordinary lease income and $₫ 9$ should not be used.

The problem arises in the case when there is a person who provides more than one place to rent for this marketplace. A typical case is a person who rents for himself many flats only for the purpose of "sub renting" or providing these flats to Airbnb users. Without any doubt, there is an income tax duty for this person and based on my opinion it is a business lease, because it has all the above-mentioned signs of a business lease. I don't really think, there are many such persons who really pay income tax based on using this marketplace, but those who pay it try to search for the possibility of how to use $₫ 9$ with all of its advantages for this kind of income. 
Any person acting as a host and his own earnings from providing accommodation in this way may be subject to income tax. Since this marketplace is based and registered in the USA, it deals mostly with US tax law and payouts in the USA. Airbnb assists with US tax compliance, and collects taxpayer information. Even if the host is not a US taxpayer, Airbnb may still require certain information from the host.

In the USA Airbnb is required to withhold $30 \%$ on all payouts from US listings hosted by non-US persons unless valid tax treaty benefits have been claimed. ${ }^{11}$

In other countries, all hosts have to deal with tax returns and pay income tax on their own, but it would be definitely reasonable if Airbnb withheld part of all payouts all around the world. All payouts in Airbnb should be subject to income tax everywhere and tax deduction would be a guarantee of legal tax compliance. The question is, whether it would be too much administration for Airbnb to find out all the tax duties and follow all the countries' tax compliance.

\section{Conclusions}

This article deals with more than one goal. I tried to compare usage using two different contracts with the context of income tax and different possibilities of the Income Tax Act. The contract of accommodation and lease contract are two different types which could be used in different situations. Generally there is autonomy of will, so contractual parties could choose their own contract, but there are always some mandatory provisions of law and contractual parties cannot do the opposite of what is stated in mandatory provisions. One of the examples could be the provisions of the Czech Civil Code about flat lease.

An accommodation contract could be used by the owner of a flat anytime, but a lease contract could be used only for long-term lease. The disadvantage of a contract of accommodation compared to a lease contract is a slightly higher tax burden, but legal provisions for this contractual type are less strict in favour of the owner. For users who want to use the flat or house for housing, it is always better to use a lease contract because of their higher legal protection.
The other aim of this article focused on taxation of income through Airbnb. Income from hosting travellers using the Airbnb marketplace is providing accommodation and it is subject to income tax. When it is not the regular activity of the provider and not with more flats or rooms provided, then it is just subject to ordinary lease income, not business income.

\section{$\underline{\text { Abstract }}$}

This article deals with income tax, mainly in the Czech Republic related to lease income. The author tries to compare two kinds of contracts dealing with housing regarding personal income tax. There are some tax possibilities for taxpayers in relation to choosing which contract to use. One of the most important criteria in deciding which contract could be used are tax implications in the event that both kinds of contracts are in compliance with the law. One of the parts of this article deals with the taxation of income from housing provision through Airbnb.

See Czech Civil Code commentary, C.H. Beck, Praha 1994, 6th ed., 2001, p. 1068.

2 Decision of Supreme Court of Czech Republic made 22.10.1999, ref. no. 2 Cdon 1010/97. Or Decision of Supreme Court of Czech Republic made 29.5.2001, ref. no. 26 Cdo 2152/2000.

See Section 2235, paragraph 2 of Czech Civil Code.

Ref. Businessdictionary.com. [cit. 27-03-2016]. Available from < http://www.businessdictionary.com/definition/business.html\#ixzz446Vm $7 v q X>$.

5 Renting the real estate in this case is not with the aim of only profit making, basically because of its singularity, or this real estate was not purchased as a subject of profit coming from a lease, but it could be just single investment of available funds, or inheritance for the owner or something similar. It's just not the activity maintained from the beginning in order to make regular profit from lease business.

${ }^{6}$ At this point activity means: Searching for new real estate property in order to buy it with the purpose of renting it. This activity aims for regular profit of the owner.

Records of income and expenses, evidence of tangible assets that could be depreciated, records of creation and use of reserves for maintenance and repairs of tangible assets, if it is created, records of assets and liabilities in the tax year in which there is a termination of the lease, and payroll sheets if there are salaries. In contrast, the use of the option of lump sum expenditure involves "just" records of income and claims associated with the lease.

8 Judgment of Supreme Administrative Court of Czech Republic of 16.01.2011 ref. no. 5 Afs 22/2011-72, or Judgment of Supreme Administrative Court of Czech Republic of 31.03.2011 ref. no. 9 Afs 81/2010-180.

Judgment of Supreme Administrative Court of Czech Republic of 31.03.2011 ref. no. 9 Afs 81/2010-180.

${ }^{10}$ Ref. Airbnb. [cit. 27-03-2016]. Available from < https://www.linkedin.com/company/airbnb>.

${ }^{11}$ Ref. Airbnb. [cit. 27-03-2016]. Available from < https://www.airbnb.com/help/article/481/how-do-taxes-work-for-hosts>. 